\title{
Flowering phenology and pollination of ornithophilous species in two habitats of Serra da Bodoquena, Mato Grosso do Sul, Brazil
}

\author{
ROGÉRIO R. FARIA ${ }^{1}$ and ANDRÉA C. ARAÚJO ${ }^{2}$ \\ ${ }^{1}$ Programa de Pós-Graduação em Ecologia e Conservação, Universidade Federal de Mato Grosso do Sul \\ Laboratório de Ecologia, Cidade Universitária s/n, Caixa Postal 549 \\ 79070-900 Campo Grande, MS, Brasil \\ ${ }^{2}$ Departamento de Biologia, Universidade Federal de Mato Grosso do Sul, Laboratório de Ecologia \\ Cidade Universitária s/n, Caixa Postal 549, 79070-900 Campo Grande, MS, Brasil \\ Manuscript received on May 6, 2009; accepted for publication on November 16, 2009
}

\begin{abstract}
The aim of this study is to describe interactions between hummingbirds and ornithophilous species at Serra da Bodoquena in midwest Brazil, with focus on flowering phenology and pollination of these plant species. In two habitats, gallery forest and semi-deciduous forest, data on flowering phenology of ornithophilous species were collected monthly over 14 months. In addition, data on morphology and floral biology, as well as visitor frequency and hummingbird behavior, were recorded. The studied community contained eight ornithophilous plant species and six hummingbird species. The ornithophilous species flowered throughout the year, and the greatest abundance of flowers was at the end of the rainy season and the beginning of the dry one. The hermit hummingbird Phaethornis pretrei and females of Thalurania furcata, were the most similar in floral resource use. Acanthaceae is the most representative family of ornithophilous plant species in Serra da Bodoquena and, thus, represents the main food source for hummingbirds. Ruellia angustiflora is especially important because it flowers continuously throughout the year and is a significant food resource for P. pretrei, which is the main visitor for this plant guild.
\end{abstract}

Key words: flowering, floral resources, hummingbirds, ornithophily, Acanthaceae, circular statistics.

\section{INTRODUCTION}

Phenology and pollination are two major factors in the reproductive biology of plant species (Rathcke and Lacey 1985). Phenology studies provide data on annual cycles and seasonal rhythms of individual plants, availability of community resources, and interactions between plants and animals that depend on these resources such as herbivores, pollinators and seed dispersers (Sarmiento and Monasterio 1983, Talora and Morellato 2000). Pollination studies have contributed with useful information regarding the degree of mutual dependence among species, reproductive ecology of plant communities, and resource supply for pollen vectors (Smith-Ramírez et al. 2005).

Correspondence to: Andréa Cardoso Araújo

E-mail: andreaa@nin.ufms.br
Bird-pollinated or ornithophilous plants are usually characterized by having brightly colored (e.g. red or yellow) odorless flowers, tubular and evenly curved corollas, diurnal anthesis and sucrose-rich nectar (Faegri and Van der Pijl 1980). A common feature in ornithophilous communities is the occurrence of species that flower throughout the year, with little seasonal variation and reproductive asynchrony within a species (Wolf et al. 1976, Sazima et al. 1996). This phenological pattern is associated with long-lived pollinators that set fixed daily foraging routes (Gentry 1974).

Hummingbirds (Trochilidae) depend on nectar over most of their life cycles (Wolf 1970), and visit flowers to sustain their daily energy balance. The family Trochilidae comprises about 118 genera and 330 
species, with 82 species currently identified in Brazil (Grantsau 1988). Extant hummingbirds are restricted to the Americas and represent 10\% of the South American avifauna (Grantsau 1988). In the neotropics, hummingbirds are the main vertebrate pollinators (Bawa 1990) and may account for the pollination of two to $15 \%$ of angiosperms in a given community (Feinsinger 1983).

The interactions between hummingbirds and flowers in the state of Mato Grosso do Sul, midwest Brazil, are poorly known. Only one study, in the south Pantanal wetlands on naturally vegetated fragments (“capões"), has been conducted in this area (Araújo and Sazima 2003). Serra da Bodoquena is situated near south Pantanal and might function as a species source for the lowlands (Brown-Junior 1984). Therefore knowledge on hummingbird-flower interactions in the surroundings could add useful information in the wetlands as well. Thus, the goals of the present study were:

1. to identify the ornithophilous species in Serra da Bodoquena and to obtain data on their floral biology in two habitats: a riparian area and a semideciduous forest;

2. to record the flowering phenology and mean flowering date of the ornithophilous plant species;

3. to document which hummingbird species visit ornithophilous plants and to record visitation frequency;

4. to assess the similarity among hummingbird species regarding their use of ornithophilous species.

\section{MATERIALS AND METHODS}

Serra da Bodoquena is located in the mid-south region of the state of Mato Grosso do Sul, Brazil. This area is bordered by the Paraguay River Depression (Pantanal plain) to the north and west, the Miranda River basin to the east, and the Apa River basin to the south. Elevation ranges from 400 to $650 \mathrm{~m}$ (Boggiani and Coimbra 1995). The climate is tropical and warm - Aw (Köppen 1948), with average annual temperatures between 20 and $22^{\circ} \mathrm{C}$. The rainy season extends from November to March, and total annual rainfall is roughly $1500 \mathrm{~mm}$. The main physiognomies are cerrado (savanna), stationary deciduous forest, stationary semi-deciduous forest, and riparian forest.
Data were collected between July 2005 and August 2006 in the surrounding of Rancho Branco Farm, in the municipality of Bodoquena. Ornithophilous species (sensu Faegri and van der Pijl 1980) were sampled every month during four to five day excursions to two studied habitats: a riparian forest (RF) along the Salobrinha stream $\left(20^{\circ} 41^{\prime} 03^{\prime \prime} \mathrm{S}-56^{\circ} 47^{\prime} 11^{\prime \prime} \mathrm{W}\right)$ and a semideciduous forest (SDF) $\left(20^{\circ} 39^{\prime} 58^{\prime \prime} \mathrm{S}-56^{\circ} 45^{\prime} 52^{\prime \prime} \mathrm{W}\right)$. A $6000 \mathrm{~m}^{2}$ belt transect $(1000 \mathrm{~m}$ long $\times 6 \mathrm{~m}$ wide) was established in each of the habitats. Phenological data (number of flower buds and open flowers) were recorded monthly at predetermined individuals.

For half of the documented ornithophilous plant species (Ruellia brevifolia, Ruellia angustiflora, Seemannia sylvatica and Lophostachys floribunda), flowering phenology was observed in 20 individuals. Fewer individuals of the remaining plant species were observed (Manettia rojasiana and Justicia ramulosa: $\mathrm{N}=5$; Ananas ananassoides: $\mathrm{N}=8$; Geissomeria tetragona: $\mathrm{N}=$ 10) because these were the only individuals that were present in the sampling area.

For ornithophilous species with open flowers, their place of occurrence, habit, height, number of open flowers per day, corolla orifice diameter and length, and main color of calyx, corolla and bracts were recorded. The concentration of nectar solutes was measured using a pocket refractometer, and nectar volume was measured using micropipettes, both in previously bagged flowers (Dafni et al. 2005). Vouchers of all plant species were collected for identification and, then, housed in the herbaria of Campo Grande (CGMS/UFMS) and EMBRAPA - Embrapa Beef Cattle (CPAP).

Hummingbird visits to the flowers were generally recorded between $0800 \mathrm{~h}$ to $1100 \mathrm{~h}$, and $1400 \mathrm{~h}$ to $1700 \mathrm{~h}$. Hummingbirds were identified through direct observations, photographs, taken during the visits, and illustrated guides (Ruschi 1982, Grantsau 1988). For species with evident sexual dimorphism, males and females were treated separately. Time and frequency of visits (number of visits per number of observed flowers per hour) were recorded. Visits were also recorded as pollination (legitimate visitation, i.e., the hummingbirds made contact with the anthers and stigma) or nectar robbing (illegitimate visitation, i.e., no contact with anthers and stigma). Hummingbird behavior was also 
assessed during visitation. We sub-divide hummingbird visitors into the following categories: major visitor was designated for the hummingbird species with the highest visitation frequency that performed only legitimate visits; secondary visitor for those that visited flowers less frequently than the major visitor and performed both legitimate and illegitimate visits; and occasional visitor for those that performed sporadic legitimate and illegitimate visits, which were less frequent than those performed by major and secondary visitors.

Frequency of flowering throughout the year was plotted on a circular histogram. A Rayleigh test (Z) for circular distribution (software: Oriana 2.0, Kovach 2004) was used to calculate the mean flowering date for the guild of ornithophilous species and the concentration (r) of individuals around this mean (Morellato et al. 1989). The vector length in the graph is related to the concentration value that ranges from 0 to 1 , and the mean angle of frequency distribution (mean date) is indicated by the arrow. The potential overlap of different hummingbird species in their use of floral resources was assessed by an analysis of clustered matched-pair data and a Jaccard's similarity index (Harmer et al. 2001).

\section{RESULTS}

\section{ORNITOPHILOUS SPECIES}

Eight ornithophilous species were found in the study area; five of these belonged to the family Acanthaceae and three belonged to Gesneriaceae, Rubiaceae and Bromeliaceae. Manettia rojasiana (Rubiaceae) is a liana, whereas the other seven species are herbaceous (Table I). All ornithophilous species occurred in the understory and have a mean height that ranged from 0.2 to $1.2 \mathrm{~m}$.

Ruellia angustiflora and Seemannia sylvatica were found exclusively in RF, and Justicia ramulosa, Lophostachys floribunda and Ananas ananassoides occurred only in SDF. Ruellia brevifolia, Manettia rojasiana and Geissomeria tetragona were present in both habitats.

The mean number of flowers opening daily ranged from 1.6 to 23.4 per individual. Seemannia sylvatica and $G$. tetragona produced the lowest means, in contrast to $M$. rojasiana that had the greatest number of flowers opened daily (Table I).

\section{PhenOlOGY OF ORNITHOPHILOUS SPECIES}

Lophostachys floribunda, A. ananassoides, G. tetragona and $J$. ramulosa flowered within a specific period and, thus, can be considered annual (Fig. 1). Even though $S$. sylvatica and $M$. rojasiana had two flowering events during the study period (one in 2005 and another in 2006), these cycles did not occur in the same annual cycle and, hence, these species were also considered to be "annual" regarding the frequency of flowering episodes. Ruellia angustiflora was the only species flowering throughout the year, and Ruellia brevifolia was the sole species exhibiting a "sub-annual" flowering pattern (sensu Newstrom et al. 1994) (Fig. 1). Flowering was "brief" in $A$. ananassoides, "intermediate" in L. floribunda, G. tetragona, S. sylvatica, J. ramulosa and $M$. rojasiana, and "extended" in both Ruellia species (sensu Newstrom et al. 1994).

\section{Guild Phenology}

Circular analysis revealed that the mean flowering date of the ornithophilous species in the studied habitats is June $2^{\text {nd }}$ (Fig. 2) $(Z=30.94 ; p<0.001)$, with moderate synchrony $(r=0.44)$. The greatest flowering frequency was recorded in July 2005 (28.91\%) and in April and May 2006 (31.25\% and 26.56\%, respectively). The lowest frequencies were recorded in November $(1 \%)$, December $(3.13 \%)$ and January $(3.13 \%)$ of 2005 , and in July 2006 (4.69\%) (Fig. 2).

\section{FLOWER DENSITY}

The highest density of ornithophilous flowers (240 flowers per hectare) occurred in April in the SDF. No ornithophilous flowers were found in the SDF in September, November and December 2005, or in January and June 2006 (Fig. 3). The flowering peak in the RF was not pronounced, and the highest flower densities occurred in July (65 flowers per hectare), September (48 flowers per hectare) and December of 2005 (38 flowers per hectare), as well as in April (five flowers per hectare), May (58 flowers per hectare) and July of 2006 (45 flowers per hectare) (Fig. 3). No ornithophilous flowers were recorded in the RF area in October. 


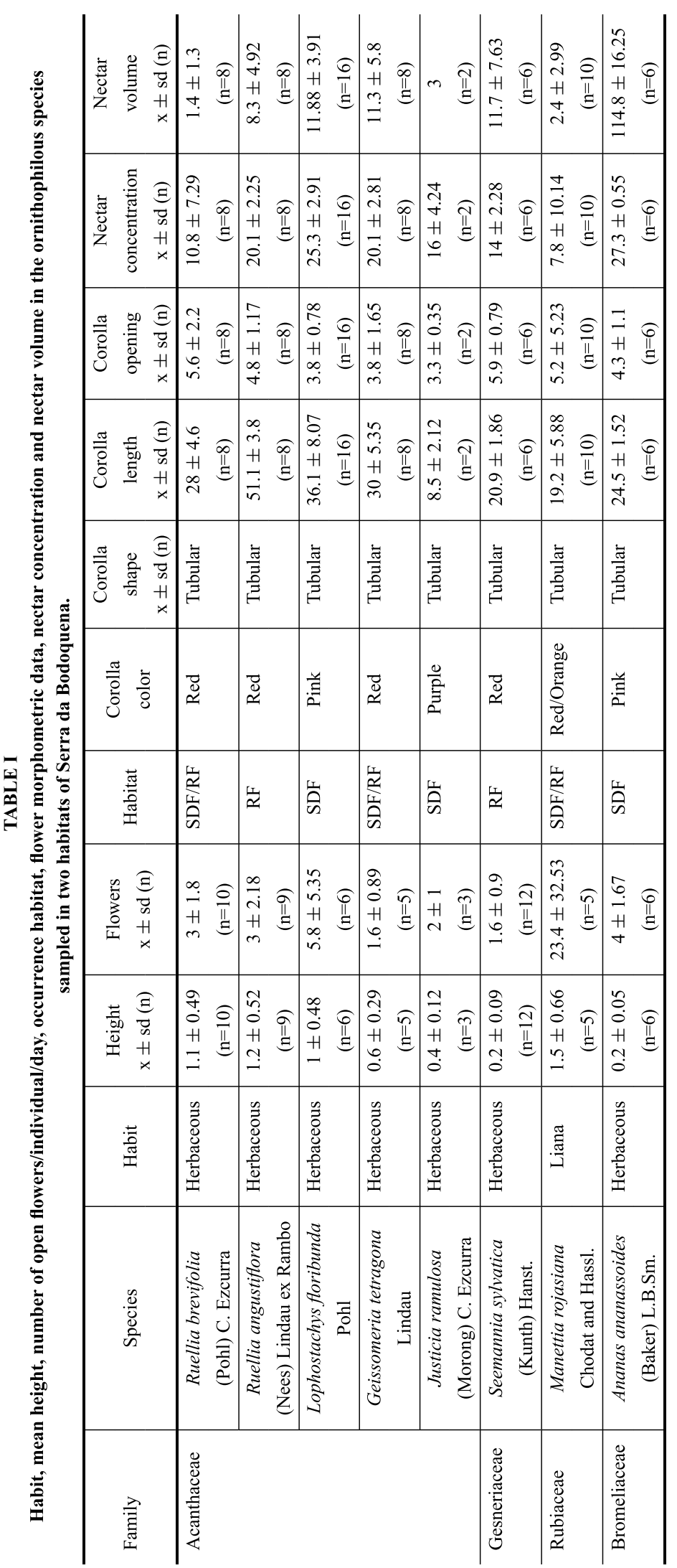




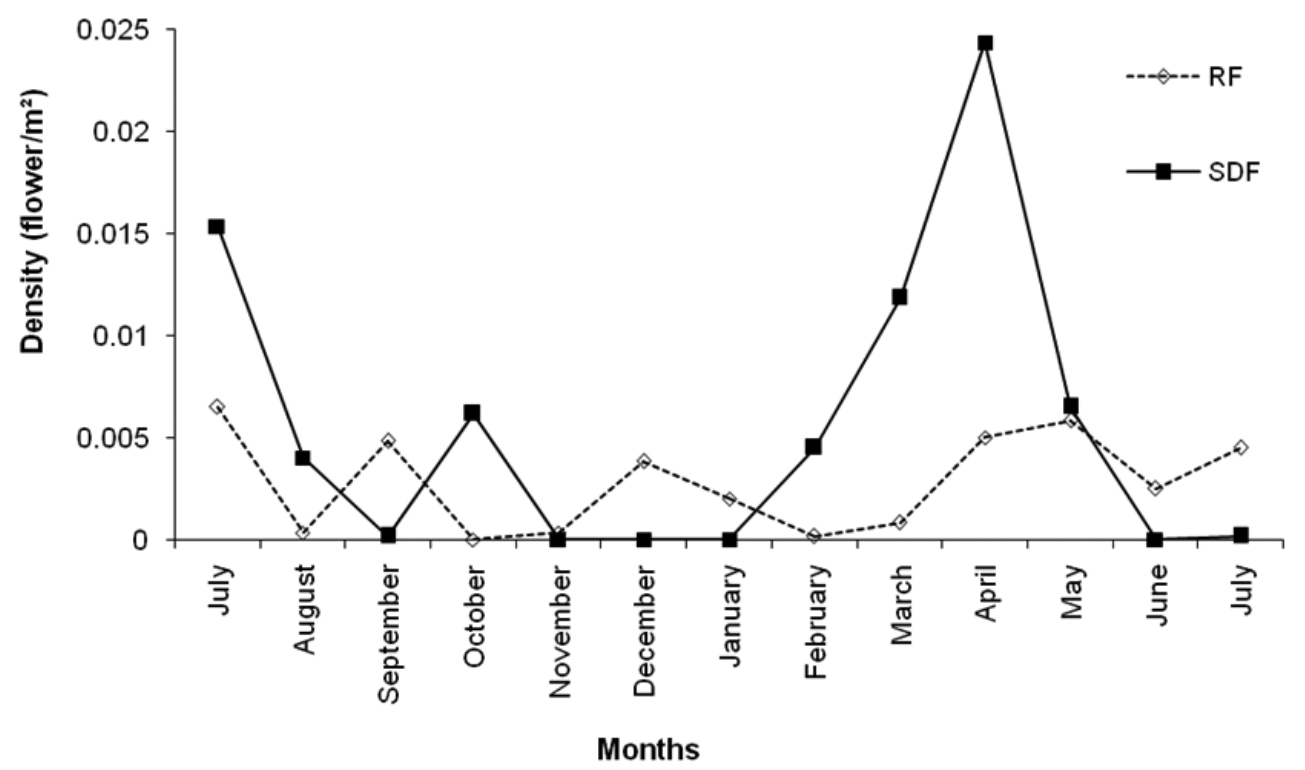

Fig. 1 - Flowering periods $(\boldsymbol{\square})$ of eight ornithophilous species from two habitats in Serra da Bodoquena from June 2005 to July 2006.

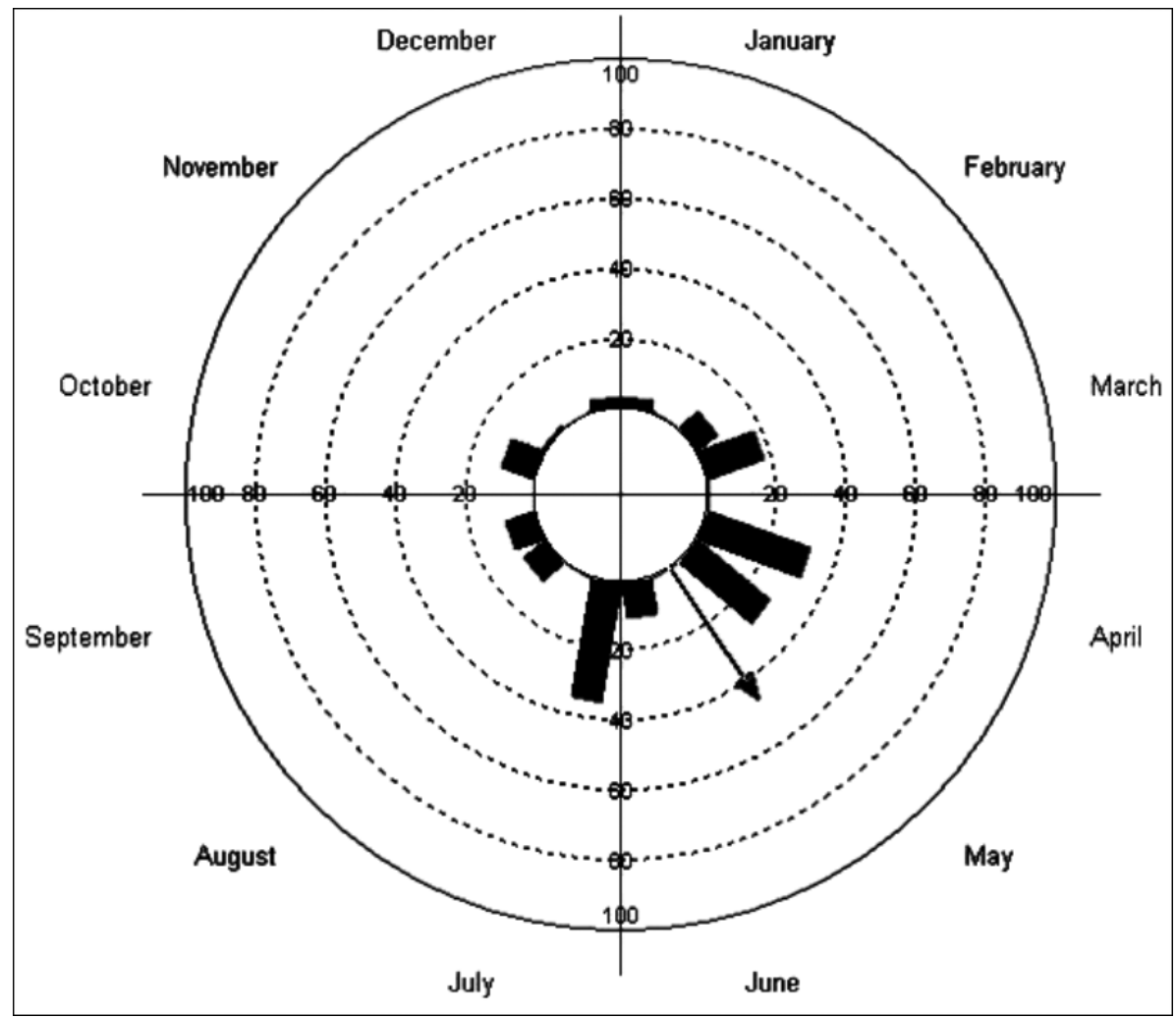

Fig. 2 - Cumulative circular histogram for flowering periods of ornithophilous species in two habitats of Serra da Bodoquena from June 2005 to July 2006. The axis indicates frequency scale, and the bars indicate the frequency of flowering individuals in the guild of ornithophilous species in every month. The arrow indicates mean flowering date. 


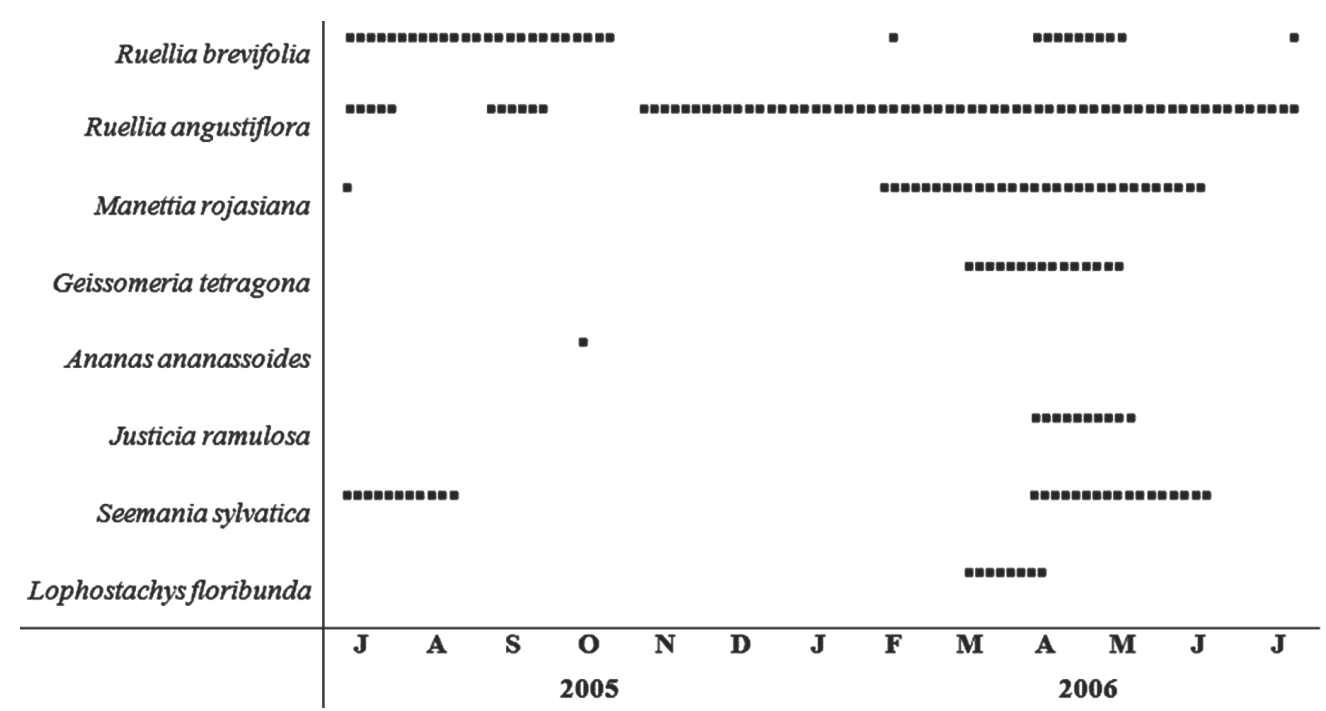

Fig. 3 - Flower density in riparian and semi-deciduous forests at Serra da Bodoquena from June 2005 to July 2006.

\section{Flower Morphology AND NeCtAR}

The recorded species had tubular corollas, which were mostly red ( $R$. brevifolia, $R$. angustiflora, S. sylvatica and G. tetragona) or red and orange (M. rojasiana). Lophostachys floribunda and A. ananassoides were pink, and $J$. ramulosa was purple. Mean corolla length ranged from $8.5 \mathrm{~mm}$ in $J$. ramulosa to $51.1 \mathrm{~mm}$ in $R$. angustiflora $($ Mean $=30.3 \pm 11.66, \mathrm{~N}=64)$. Mean corolla orifice diameter was $3.3 \mathrm{~mm}$ in $J$. ramulosa and $5.9 \mathrm{~mm}$ in S. sylvatica (Mean $=4.5 \pm 2.39, \mathrm{n}=64)$. The highest nectar volume and concentration was recorded in $A$. ananassoides, whereas the lowest nectar volume was recorded in R. brevifolia and the lowest nectar concentration in M. rojasiana (Table I). Mean nectar concentration in the community was $20.9 \pm 5.16 \%(\mathrm{~N}=59)$, and mean nectar volume was $26.6 \pm 53.84 \mu \mathrm{L}(\mathrm{N}=59)$.

\section{FLOWER VISITORS}

Six hummingbird species were recorded in the study area, one being the hermit (Phaethornithinae) Phaethornis pretrei (Lesson and Delattre 1839) and the five remaining being the trochilids (Trochilinae) Hylocharis chrysura (Shaw 1812), Aphantochroa cirrochloris (Vieillot 1818), Amazilia versicolor (Vieillot 1818), Thalurania furcata (Gmelin 1788) and Chlorostilbon lucidus (Shaw 1812).

The hermit $P$. pretrei was the main visitor of flowers in the community. It visited seven of the eight ornithophilous species recorded (i.e., all except L. floribunda) and always performed legitimate visits. Phaethornis pretrei was the major visitor of $R$. angustiflora, $R$. brevifolia, S. sylvatica and $G$. tetragona, and the secondary visitor of $A$. ananassoides, $M$. rojasiana and $J$. ramulosa (Table II).

Females of $T$. furcata were frequent visitors to five ornithophilous species (Table II). They were the major visitors of $A$. ananassoides and $M$. rojasiana, and the secondary visitors of $R$. angustiflora, $S$. sylvatica and $G$. tetragona.

The Trochilinae $H$. chrysura, which visited three ornithophilous species, was the only hummingbird that visited L. floribunda and was a sporadic visitor to $R$. angustiflora and G. tetragona (Table II). It behaved as a nectar robber of $R$. angustiflora flowers and as a legitimate visitor to the other two species.

Amazilia versicolor and males of T. furcata visited flowers of two species each (Table II). Amazilia versicolor was the major visitor to J. ramulosa and a sporadic visitor to $M$. rojasiana; it always performed legitimate visits. Males of $T$. furcata were sporadic visitors to $R$. angustiflora (as nectar robbers or legitimate visitors) and to M. rojasiana (as legitimate visitors). Aphantochroa cirrochloris performed legitimate and sporadic visits to $R$. angustiflora flowers (Table II).

The hummingbird $P$. pretrei visited grouped and sparse flowers in foraging bouts at regular 40-60 min 
TABLE II

Frequency of hummingbird visitation to the ornithophilous species (number of visits/number of observed flowers/hour) during 8166 min of observation in two habitats (Riparian and semi deciduous forests) of Serra da Bodoquena.

( $=$ legitimate visitation, $\mathrm{i}$ = illegitimate visitation).

\begin{tabular}{|c|c|c|c|c|c|c|c|}
\hline & $\begin{array}{c}\text { Phaethornis } \\
\text { pretrei }\end{array}$ & $\begin{array}{c}\text { Thalurania } \\
\text { furcata male }\end{array}$ & $\begin{array}{c}\text { Thalurania } \\
\text { furcata female }\end{array}$ & $\begin{array}{c}\text { Hylocharis } \\
\text { chrysura }\end{array}$ & $\begin{array}{c}\text { Aphantochroa } \\
\text { cirrochloris }\end{array}$ & $\begin{array}{c}\text { Amazilia } \\
\text { versicolor }\end{array}$ & $\begin{array}{c}\text { Duration } \\
\text { (min) }\end{array}$ \\
\hline Ruellia brevifolia & $5.82(1)$ & 1 & I & 1 & 1 & 1 & 550 \\
\hline Ananas ananassoides & $1.68(1)$ & 1 & $9.18(1)$ & 1 & 1 & 1 & 205 \\
\hline Ruellia angustiflora & $1.62(1)$ & 0.006 (i) & $0.42(1 / \mathrm{i})$ & 0.006 (i) & $0.06(1)$ & I & 2826 \\
\hline Seemannia sylvatica & $1.56(1)$ & 1 & $0.36(1 / \mathrm{i})$ & 1 & 1 & 1 & 1775 \\
\hline Manettia rojasiana & $0.6(1)$ & $0.12(1)$ & $3.42(1)$ & I & 1 & $0.12(1)$ & 1162 \\
\hline Geissomeria tetragona & $4.08(1)$ & I & $2.94(1)$ & $0.36(1)$ & 1 & 1 & 536 \\
\hline Lophostachys floribunda & 1 & 1 & I & $7.26(1)$ & 1 & 1 & 1067 \\
\hline Justicia ramulosa & $11.4(1)$ & 1 & 1 & 1 & 1 & $17.16(1)$ & 45 \\
\hline
\end{tabular}

intervals. Females of Thalurania furcata defended territories around M. rojasiana and $R$. angustiflora flowers, but also visited $G$. tetragona, A. ananassoides and $S$. sylvatica flowers in regular 40-50 min intervals. Hylocharis chrysura defended territories around L. floribun$d a$ flowers, and occasionally visited $G$. tetragona and $R$. angustiflora. The hummingbirds Ap. cirrochloris and $A m$. versicolor were observed sporadically in the study area defending territories around $R$. angustiflora and $M$. rojasiana. Males of T. furcata were recorded sporadically visiting $M$. rojasiana and $R$. angustiflora flowers.

Hummingbirds exhibiting high similarity in the use of the ornithophilous flowers were P. pretrei and females of T. furcata, followed by Am. versicolor and males of T. furcata (Fig. 4).

\section{DISCUSSION}

\section{ORNITHOPHILOUS SPECIES}

The predominance of ornithophilous species from Acanthaceae at Serra da Bodoquena was similar to that found in communities of ornithophilous species in Mexico (Toledo 1975) and in a forest fragment in southeastern Brazil (Abreu and Vieira 2004), where most ornithophilous species were from Acanthaceae and Rubiaceae. In Atlantic and Amazonian rainforest areas, the most representative ornithophilous families are Rubiaceae, Gesneriaceae and Bromeliaceae (e.g. Snow and Snow 1980, Sazima et al. 1996, Lasprilla and Sazima 2004). However, in the south Pantanal, there is no predominance of any botanical family (Araújo and Sazima 2003).

The high proportion of herbaceous species in the studied community is influenced by Acanthaceae, which are all herbaceous and account for $63 \%$ of the sampled plants. Other studies on ornithophilous communities report a marked predominance of epiphytes and shrubs (Arizmendi and Ornelas 1990, Sazima et al. 1996), which may be affected by the habits of the plant families that are most frequent at those sites.

The richness of six ornithophilous species recorded in Serra da Bodoquena was comparable to that recorded in the "capões" of Pantanal (Araújo and Sazima 2003). However, richness in other localities ranged from 15 (Arizmendi and Ornelas 1990) to 50 species (Stiles 1978). Comparisons with neighboring communities could explain the differences of predominance in habits and families, as well as the richness patterns here found. However, hummingbird-flower interactions have been insufficiently studied in and around the research area.

\section{Phenology OF The ORNITHOPHILOUS SPECIES}

Most ornithophilous species had annual flowering patterns of intermediate duration. This suggests that these plants may have some degree of seasonality regarding flowering phenology. Given that the sampled plants are, in general, herbaceous, their response to environmental changes may be rapid and highly dependent upon water availability (Sarmiento and Monasterio 1983, but see Borchert 1983). Because climatic data for the studied area are non-existent, it was not possible to assess whether water availability triggers flowering in the recorded species. Moreover, this study was performed 


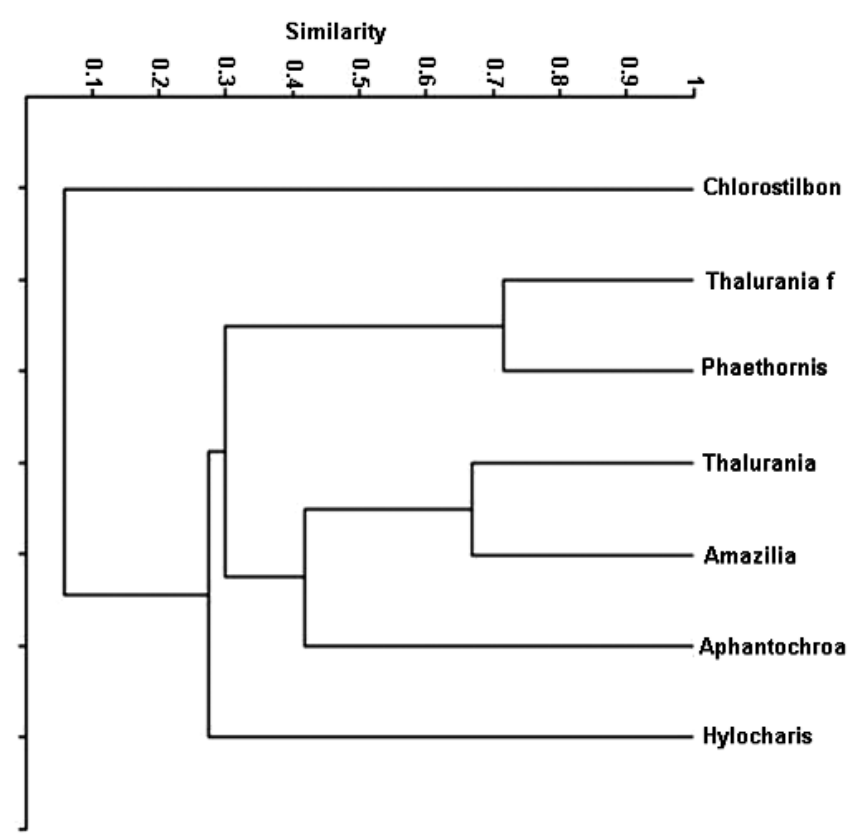

Fig. 4 - Cluster analysis representing the similarity (Jaccard's index) among the hummingbird species (Chlorostilbon lucidus, male and female of Thalurania furcata, Phaethornis pretrei, Amazilia versicolor, Aphantochroa cirrochloris and Hylocharis chrysura) concerning their use of floral resources in two habitats of Serra da Bodoquena.

over the course of a single year, yet good knowledge of phenological patterns necessarily requires study over several years (D’Eça-Neves and Morellato 2004).

\section{Guild Phenology}

The concentration value (r) determined by circular analyses indicates moderate synchrony among the individuals in the community, i.e., resources are regularly available for hummingbirds throughout the entire year. In addition, according to the classification of Newstrom et al. (1994) that is based on the frequency of flowering events in a guild, the flowering of ornithophilous species is deemed continuous in the studied community. This continuous flowering is characterized by flowering throughout the year with short, sporadic absences of flower availability. Despite the low richness of ornithophilous species, flowers were available throughout the year, thereby ensuring the availability of resources for hummingbirds at the study site. This is critical to the hummingbirds because they have a long life cycle and, thus, require resources throughout the year in order to supply their daily energy demands (Wolf 1970, Gentry 1974, Stiles 1975). However, differences in flower availability between habitats occurred, and in months of flower absence in a given habitat (e.g. October in RF), hummingbirds must make local migrations searching for flowers in other habitats.

\section{FLOWER DENSITY}

The production of flowers and buds was more pronounced at the end of the rainy season and at the beginning of the dry season than at other times, as shown by the Rayleigh test (Z). Flowering events of ornithophilous plants in the dry season may be especially attractive to hummingbirds because such events are generally fewer than those in the rainy season, when more floral resources are expected to be found in the community (Sarmiento and Monasterio 1983) and when hummingbirds may use non-ornithophilous species more often than ornithophilous ones. In fact, hummingbirds can visit both flower types, despite their particular pollination adaptations (Araújo and Sazima 2003). For instance, six non-ornithophilous species in SDF and one in RF are known to be visited by hummingbirds (L.C. Rodrigues, personal communication). Another advantage that dry season flowers may have is the lack of heavy rains that harm or cause flowers and buds to fall, as observed in Ruellia angustiflora in the study area. In addition, leaf 


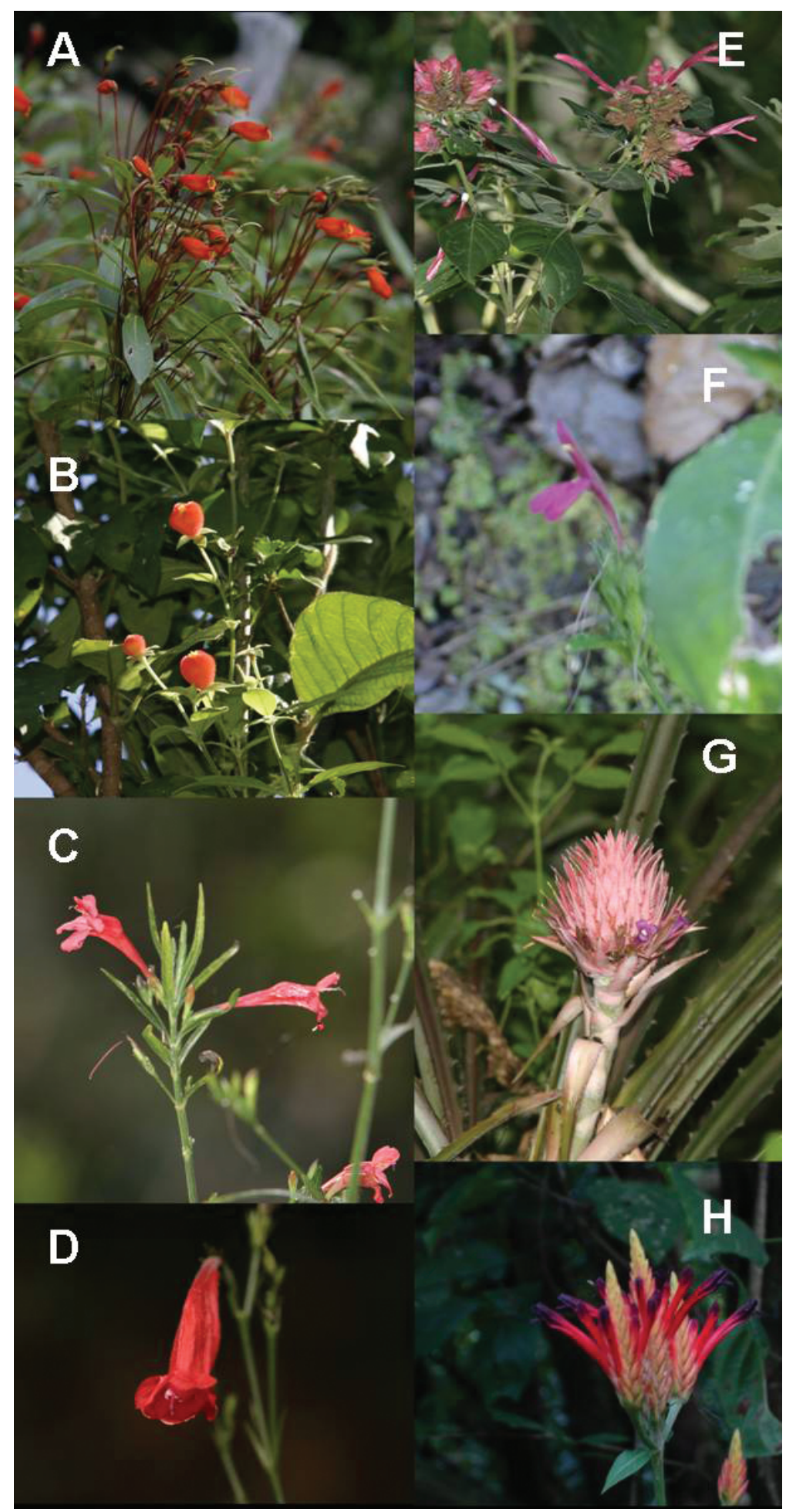

Fig. 5 - Ornithophilous species recorded at Serra da Bodoquena: A) Seemannia sylvatica, B) Manettia rojasiana, C) Ruellia angustiflora, D) Ruellia brevifolia, E) Lophostachys floribunda, F) Justicia ramulosa, G) Ananas ananassoides, and H) Geissomeria tetragona. Pictures by Eduardo Camargo (A, B, C, D, E, G) and Rogério Rodrigues Faria (F, H). 
fall in the dry season increases flower visualization and favors the pollinator activity (Janzen 1967). In contrast to these results, other Brazilian neotropical communities with weak (e.g. Sazima et al. 1996, Buzato et al. 2000) or marked seasonality (Araújo and Sazima 2003) have higher flower density at the beginning of and throughout the rainy season.

\section{Flower Morphology AND NeCTAR}

Characteristics of corolla coloration and shape, nectar volume and concentration, and floral morphometry in the ornithophilous species from Serra da Bodoquena are similar to those described in other neotropical areas. In these areas, the mean corolla length of ornithophilous species varied from $6.7 \mathrm{~mm}$ (e.g., Vasconcelos and Lombardi 2001) to $100-115 \mathrm{~mm}$ (e.g. Araújo and Sazima 2003) and corolla orifice diameter from $1.8 \mathrm{~mm}$ (e.g. Smith et al. 1996) to $20 \mathrm{~mm}$ (e.g. Temeles et al. 2002). Thus, species from the studied community had flowers with short to moderate corolla lengths and narrow widths, compared to these previously reported values. Nectar amount in neotropical ornithophilous species is commonly high (ranging on average from 15 to $123 \mu 1$ ), with diluted concentration (22-26\% of sugar; Howe and Westley 1997, McDade and Weeks 2004). In contrast, ornithophilous species in Serra da Bodoquena have low nectar volumes and reduced nectar concentrations.

\section{FLORAL VISITORS}

In the present study, four of the 11 hummingbird species reported at Serra da Bodoquena during an avian survey (Pivatto et al. 2006) were recorded during the present study. This survey included 24 sites in the counties of Bonito, Jardim, Bodoquena and Porto Murtinho, and involved over $500 \mathrm{~h}$ of sampling effort and literature data. The other two hummingbird species recorded here, Aphanthocroa cirrochloris and Chlorostilbon lucidus, had not previously been recorded at Serra da Bodoquena. Following a list of Pantanal birds (Tubelis and Tomas 2003), Ap. cirrochloris was the only species not observed in the lowlands as well. The other species were recorded in both the north and south Pantanal.

The hermit $P$. pretrei is the major visitor of the studied community in terms of number of visited species, frequency and mode of visitation (mainly legiti- mate). This result differs from that recorded in natural fragments of the Pantanal (Araújo and Sazima 2003), where Hylocharis chrysura was the major visitor.

The community roles of "high-reward trapliner", "low-reward trapliner", "territorial", and "generalist" (sensu Feinsinger and Colwell 1978) were fulfilled by the hummingbirds visiting the ornithophilous flowers in the studied community. The hummingbird P. pretrei was both a high- and low-reward trapliner because of the corolla lengths and nectar offer in the visited flowers; and it visited flowers in foraging bouts at regular intervals. This visiting behavior, as already described for these species in other sites (Sazima 1981, Machado and Sazima 1987, Piratelli 1997, Vasconcelos and Lombardi 2001), promotes cross-pollination. However, intra and interspecific antagonistic interactions of $P$. pretrei were also observed, especially when it visited patches of $R$. angustiflora. These patches occasionally contained a large number of flowers (around 100 flowers/patch) that attracted many hummingbirds. Records of antagonistic behavior in the Phaethornithinae family are uncommon and have been described in only a few studies (e.g. Sazima et al. 1995).

Hylocharis chrysura and females of T. furcata behaved either as territorial or low-reward trapliners. Aphantochroa cirrochloris, Am. versicolor, and males of T. furcata were considered generalists because they visited sparse flowers sporadically and used flower patches that were unguarded by other hummingbirds. The community roles described here were not fixed for a given hummingbird species. This indicates that the visiting behavior of these birds is closely related to resource availability rather than morphological characteristics, as wing disc loading (ratio of body weight to a circle whose diameter is wing span; Feinsinger and Colwell 1978), body size, bill morphology and feet size. This situation was suggested by Feinsinger and Colwell (1978) and is often described in other communities (Sazima et al. 1996, Buzato et al. 2000). Moreover, the hummingbirds reported in the present study are nomadic, have a generalist use of floral resources, and are broadly distributed (Ruschi 1982, Grantsau 1988).

Phaethornis pretrei and females of T. furcata displayed the greatest similarity in species of plant(s) they visited. This high degree of overlap in resource use in- 
volving one Phaethornithinae and one Trochilinae has been observed in other Brazilian communities. Piacentini and Varassin (2007) described the pair Ramphodon naevius and Thalurania glaucopis in a study on bromeliad-hummingbird interaction in southern Brazil. Sazima et al. (1996) and Buzato et al. (2000) recorded the pair Phaethornis eurynome and Leucochloris albicollis in an area of Atlantic forest in southeastern Brazil. This indicates that morphology alone does not account for hummingbird organization in a given community. Instead, organizational patterns are better explained by morphological-behavioral attributes together with resource availability and hummingbird vagility, i.e., permanence time, in a given environment (Feinsinger and Colwell 1978).

In conclusion, Acanthaceae is the most representative ornithophilous family in Serra da Bodoquena. It includes the greatest number of species that provide resources to the hummingbirds and, along with other ornithophilous families, flowers throughout the year. The period of the highest abundance of floral resources is at the end of the rainy and beginning of the dry season. For this plant guild, the hermit $P$. pretrei is the major visitor, and $R$. angustiflora is an important food source because it flowers continuously throughout the year.

\section{ACKNOWLEDGMENTS}

We thank L.C. Rodrigues, E. Camargo and E.A. Doná for their assistance in the field work; L.C. Garcia for help with circular statistics; V. Pott for identifying the plants; M.F. Vieira, F.N. Ramos, M.R. Sigrist, J. RagusaNetto and I.C. Machado for the critical review of the manuscript. Coordenação de Aperfeiçoamento de Pessoal de Nível Superior (CAPES) and Conservação Internacional (CI) provided R.R. Faria with a grant; Fundação de Apoio ao Desenvolvimento do Ensino, Ciência e Tecnologia do Estado de Mato Grosso do Sul (FUNDECT) provided financial support to the project.

\section{RESUMO}

O objetivo deste estudo é descrever as interações entre beijaflores e espécies ornitófilas na Serra da Bodoquena na região Centro-Oeste do Brasil, com foco na fenologia de floração e polinização destas espécies vegetais. Em dois habitats, mata ciliar e floresta semi-decídua, dados de fenologia de floração de espécies ornitófilas foram coletados mensalmente ao longo de 14 meses. Além disso, dados de morfologia e biologia floral bem como a frequência dos visitantes e o comportamento dos beija-flores foram registrados. A comunidade estudada contém oito espécies de plantas ornitófilas e seis espécies de beija-flores. As espécies ornitófilas floresceram todo o ano, e a maior abundância de flores foi no final da estação chuvosa e início da seca. O beija-flor eremita Phaethornis pretrei e a fêmea de Thalurania furcata foram os mais similares no uso dos recursos florais. Acanthaceae é a família mais representativa das espécies vegetais ornitófilas na Serra da Bodoquena e representa a principal fonte de recurso para os beija-flores. Ruellia angustiflora é especialmente importante porque floresce continuamente ao longo do ano e é uma importante fonte de recurso para $P$. pretrei, que é o principal visitante floral para esta guilda de plantas

Palavras-chave: floração, recurso floral, beija-flores, ornitofilia, Acanthaceae, estatística circular.

\section{REFERENCES}

ABREU CRM AND VIEIRA MF. 2004. Os beija-flores e seus recursos florais em um fragmento florestal de Viçosa, sudeste brasileiro. Lundiana 5(2): 129-134.

ARAújo AC AND SAZIMA M. 2003. The assemblage of flowers visited by hummingbirds in the "capões" of southern Pantanal, Mato Grosso do Sul, Brazil. Flora 198(6): 427-435.

ARIZMENDI MC AND ORNELAS JF. 1990. Hummingbirds and their floral resources in a tropical dry forest in Mexico. Biotropica 22(2): 172-180.

BAWA KS. 1990. Plant-pollinator interactions in tropical rain forests. Annu Rev Ecol Syst 21: 399-422.

Boggiani PC AND CoImbra AM. 1995. Quaternary limestone of the Pantanal area, Brazil. An Acad Bras Cienc 67: 343-349.

BorChert R. 1983. Phenology and control of flowering in tropical trees. Biotropica 15(2): 81-89.

BROWN-JUNIOR K. 1984. Zoogeografia da região do Pantanal Mato-grossense. 389 In: SIMPÓSIO SOBRE OS RECURSOS NATURAIS E SÓCIO-ECONÔMICOS DO PANTANAL. Brasília, DF, Brasil, Anais EMBRAPA, p. 137-178.

Buzato S, Sazima M And Sazima I. 2000. Hummingbird-pollinated floras at three Atlantic Forest sites. Biotropica 32(4b): 824-841.

Dafni A, Kevan PG And Husband BC. 2005. Practical Pollination Biology, $1^{\text {st }}$ ed., Ontario, Enviroquest Ltd., $590 \mathrm{p}$. 
D’Eça-Neves FF And Morellato PC. 2004. Métodos de amostragem e avaliação utilizados em estudos fenológicos de florestas tropicais. Acta Bot Bras 18: 99-108.

FAEGRI K AND VAN DER PIJL L. 1980. The principles of pollination ecology, $2^{\text {nd }}$ ed., Toronto, Pergamon Press, $244 \mathrm{p}$.

FEINSINGER P. 1983. Coevolution and pollination. In: FUTUYMa DJ AND Slatkin M (Eds), Coevolution, Massachusetts, Sinauer Associates, p. 282-310.

FEINSINGER P AND COLWEll RK. 1978. Community organization among neotropical netar-feeding birds. Am Zool 18: 779-795.

Gentry AH. 1974. Coevolutionary patterns in Central American Bignoniaceae. Ann Mo Bot Gard 61: 728-759.

Grantsau R. 1988. Os beija-flores do Brasil, $1^{\text {a }}$ ed., Rio de Janeiro, RJ, Brasil, Editora Expressão e Cultura, 233 p.

HARMer O, Harper DAT AND RyAn PD. 2001. Past: Paleontological Statistics software package for education and data analysis. Palaeontol Electron 4: 9.

$<$ http//flok.uio.no/ohammer/past $>$ (accessed 10 October 2006).

Howe HF AND Westley LC. 1997. Ecology of pollination and seed dispersal. In: CRAWLEY MJ (Ed), Plant Ecology. $2^{\text {nd }}$ ed., Oxford: Blackwell Scientific Pub, p. $262-283$.

JANZEN DH. 1967. Synchronization of sexual reproduction of trees within the dry season in Central America. Evolution 21: 620-637.

Köppen W. 1948. Climatología, $1^{\text {a }}$ Ed., México: Editora Fondo de Cultura Económica, 479 p.

Kovach WL. 2004. Oriana for Windows, version 2.0. Kovach Computer Services, Pentraeth.

LASPRILLA R AND SAZIMA M. 2004. Interacciones plantacolibrí en tres comunidades vegetales de la parte suroriental del Parque Nacional Natural Chiribiquete, Colombia. Ornitol Neotrop 15(Suppl): 183-190.

MACHADO IC AND SAZIMA M. 1987. Estudo comparativo da biologia floral em duas espécies invasoras Ipomoea hederifolia e I. quamoclit (Convolvulaceae). Rev Bras Biol 47: 425-436.

MCDAdE LA AND WeEKS JA. 2004. Nectar in hummingbird-pollinated Neotropical Plants I: Patterns of production and variability in 12 species. Biotropica 36(2): 196215.

Morellato LPC, Rodrigues RR, Leitão-Filho HF AND JOLY CA. 1989. Estudo comparativo da fenologia de espécies arbóreas de floresta de altitude e floresta mesófila semidecídua na Serra do Japi, Jundiaí, São Paulo. Rev Bras Bot 12: 85-98.

Newstrom Le, Frankie GW and Baker HG. 1994. A new classification for plant phenology based on flowering patterns in Lowland Tropical Rain Forest Trees at La Selva, Costa Rica. Biotropica 26: 141-159.

PIACENTINI VQ AND VARASSIN IG. 2007. Interaction network and the relationships between bromeliads and hummingbirds in an area of secondary Atlantic rain forest in southern Brazil. J Trop Ecol 23: 663-671.

Piratelli AJ. 1997. Comportamento alimentar de beijaflores em duas espécies de Hippeastrum Herb. (Amaryllidaceae) Rev Bras Biol 57: 261-273.

Pivatto MaC, Manco DG, Straube FC, Urben-Filho A And Milano M. 2006. Aves do Planalto da Bodoquena, estado do Mato Grosso do Sul (Brasil). Atual Ornit 129. Available on-line: http://www.ao.com.br $>$ Seção AO Online $>$ Artigos. (accessed 10 October 2006).

RATHCKe B AND LACEY EP. 1985. Phenological patterns of terrestrial plants. 438 Annu Rev Ecol Syst 16: 179-214.

RusCHI A. 1982. Aves do Brasil: beija-flores, volumes 4 e 5, $1^{\mathrm{a}}$ ed., Rio de Janeiro, RJ, Brasil, Expressão e Cultura.

SARMiento G AND Monasterio M. 1983. Life forms and phenology. In: Bourlière F (Ed), Ecosystems of the World: Tropical Savannas, Amsterdam, Elsevier Science, p. 79-108.

SAzima I, Buzato S And SAzIMA M. 1995. The saw-billed hermit Ramphodon naevius and its flowers in southeastern Brazil. J für Ornit 136: 195-206.

Sazima I, Buzato S ANd SAZIMA M. 1996. An assemblage of hummingbird-pollinated flowers in a montane forest in southeastern Brazil. Bot Acta 109: 149-160.

Sazima M. 1981. Polinização de duas espécies de Pavonia (Malvaceae) por beija-flores na Serra do Cipó, Minas Gerais. Rev Bras Biol 41: 733-737.

Smith CE, Stevens JT, Temeles EJ, Ewald PW, HEBERT RJ AND BONKOVSKY RL. 1996. Effect of floral orifice width and shape on hummingbird-flower interactions. Oecologia 106: 482-492.

Smith-RAmírez C, Martinez P, NuÑEZ M, GonZÁlez C AND ARMESTO JJ. 2005. Diversity, flower visitation frequency and generalism of pollinators in temperate rain forests of Chiloé Island, Chile. Bot J Linnean Soc 147: 399-416.

SNOW DW AND SNOW BK. 1980. Relationships between hummingbirds and flowers in the Andes of Colombia. Bull Br Mus Nat Hist (Zoology) 38(2): 105-139. 
STILES FG. 1975. Ecology, flowering phenology, and hummingbird pollination of some Costa Rican Heliconia species. Ecology 56: 285-301.

STILES FG. 1978. Temporal organization of flowering among the hummingbird food plants of a tropical wet forest. Biotropica 10: 194-210.

Talora DC And Morellato LPC. 2000. Fenologia de espécies arbóreas em floresta de planície litorânea do sudeste do Brasil. Rev Bras Bot 23: 13-26.

Temeles EJ, Linhart YB, Masonjones M AND MASONJONES HD. 2002. The role of flower width in hummingbird bill length-flower length relationships. Biotropica 34: 68-80.

Toledo VM. 1975. La estacionalidad de las flores utilizadas por los colibrís de una selva tropical húmeda en México. Biotropica 7: 63-70.
Tubelis DP AND Tomas WM. 2003. Bird species of the Pantanal wetland, Brazil. Ararajuba 11: 5-37.

VASCONCELOS MF AND LOMBARdi JA. 2001. Hummingbirds and their flowers in the campos rupestres of southern Espinhaço Range, Brazil. Melopsittacus 4: 3-30.

WOLF LL. 1970. The impact of seasonal flowering on the biology of some tropical hummingbirds. The Condor 72 : $1-14$.

Wolf LL, Stiles FG ANd Hainsworth FR. 1976. Ecological organization of a tropical, highland hummingbird community. J Anim Ecol 32: 349-379. 